\title{
A Study of EFL Curriculum of China's Science and Technology Institutes under Graded Teaching Model
}

\author{
Chunyan $\mathrm{He}^{1} \&$ Fei $\mathrm{Han}^{1}$ \\ ${ }^{1}$ Department of Foreign Languages, China University of Geosciences (Beijing), Beijing, China \\ Correspondence: Chunyan He, Department of Foreign Languages, China University of Geosciences (Beijing), \\ Beijing, 100083, China. Tel: 86-10-8232-2423. E-mail: hechunyan@cugb.edu.cn
}

Received: October 29, 2017 Accepted: January 6, 2018 Online Published: January 8, 2018

doi: 10.5539/elt.v11n2p44 URL: http://doi.org/10.5539/elt.v11n2p44

\begin{abstract}
Recent years, most universities and colleges have been reforming the English as a foreign language (EFL) curriculum system in China. Some reformed EFL curriculum into English for Specific Purposes (ESP) courses, for instance, while some conducted a graded teaching model in EFL teaching. However, the effect of this reform was not so good, especially at science and technology institutes. Therefore, in view of different opinions to classification of foreign language teaching, the classification scheme of English teaching was improved and rebuilt at first, based on the analysis of the learners' feedback from the perspective of learner's needs on the current EFL curriculum system of China's science and technology institutes under graded teaching model. And then a new EFL curriculum system of China's science and technology institutes under graded teaching model was designed based on learning-centered approach to course and curriculum design to promote the development of EFL teaching and China's ESP courses and accordingly meet nation's needs for cultivating international and integrated high-quality talents of foreign languages.
\end{abstract}

Keywords: graded teaching model, ESP courses, classification scheme of English teaching, EFL curriculum system

\section{Introduction}

A large number of inter-disciplinary talents for foreign languages and other disciplines, such as geosciences, law, physics, etc. in China are needed with China going toward internationalization based on "One Belt One Road", which conforms to the requirement of "cultivating a large number of international talents with an international view, knowledge of international rules, and capacity for participating in international affairs and competition" in the National Plan for Medium and Long-term Education Reform and Development (2010-2020) (Ministry of Education [MOE], 2010). English is regarded as the global lingua franca now, thus a good command of English is becoming increasingly important as international talents. And effective English as a foreign language (EFL) teaching can largely enhance learners' English competence. However, what is effective EFL teaching and how to reform the current EFL curriculum system at China's colleges and universities? Around these questions, scalars have different views. Feng (2010) proposed "disciplinary transfer", that is the elimination of the common core foreign language (CCFL) courses. Cai (2012) suggested "paving the road to academic success by EFL teaching", that is to focus on English for academic purposes (EAP) teaching. Wen (2014), however, advised that EFL curriculum system should include both of English for general purposes (EGP) and English for specific purposes (ESP) for students to choose. Their views are different, but they all agree on reforming the current EFL curriculum system.

However, there are many difficulties impeding the reform of EFL curriculum system. For example, what is the teaching objective of EGP? How to merge EGP with ESP? And what is the difference in EFL curriculum system between science and technology institutes and liberal arts colleges? Generally speaking, English proficiency of the students from science and technology institutes is a little lower than from liberal arts colleges. Nevertheless, they are demanded to have an equally good command of English for their future career development or academic studies. Hence, how to reform the current EFL curriculum system of China's science and technology institutes under graded teaching model to match and raise their current English proficiency and then to meet their future occupational needs? This paper is written to rebuild the classification scheme of English teaching and then design a new EFL curriculum system of China's science and technology institutes under graded teaching model 
based on based on learning-centred approach to curriculum design to promote the development of EFL teaching and China's ESP courses and accordingly meet nation's needs for cultivating international and integrated high-quality talents of foreign languages, taking China University of Geosciences (Beijing) (CUGB) as example.

\section{Current Situations of China's EFL Curriculum System}

\subsection{EFL Curriculum System}

As a multi-disciplinary national key university, CUGB has evolved an educational program that balances sciences, technology, arts, management, economics and law, featuring geology, natural resources, environment and geological engineering. At present there are around 15000 full-time students, only $10 \%$ of whom majors are in liberal arts. Therefore, CUGB is a science and technology institutes in China.

The EFL curriculum system of CUGB is divided into four parts, including general educational courses, disciplinary fundamental courses, specialized core courses as well as innovation and entrepreneurship. Table 1 shows that EFL courses are mainly contained in two categories, i.e. general educational courses and specialized core courses. Among these courses, specialty English for a certain discipline is taught by content teachers of each school whose instruction combines English study with the study of content but focuses on the subject matter (Leaver \& Stryker, 1989). Therefore, all the EFL courses belong to general educational courses. And furthermore, the required EFL courses are only 2 college English courses (12 credits, 192 hours) which are taken in the first year. Meanwhile, in the selective courses, EFL courses only account for $16 \%$ of humanities and social sciences courses and $4 \%$ of innovation and entrepreneurship courses. Thus, the minimum credit requirement of Bachelor Degree about EFL courses is mere 12 credits completed in the first year. As to other selective EFL courses, whether to take or not, that is students' choice. He/she could choose no course about EFL and then he/she could achieve the Bachelor Degree, as well. Thus, the English level of an undergraduate in China only can reach level 2 with the current hours of EFL courses after the four-year English learning according to The Interagency Language Roundtable (ILR) criteria (Conway, 2010; Wen, 2012).

Table 1. EFL curriculum of CUGB

\begin{tabular}{|c|c|c|c|c|c|}
\hline \multicolumn{2}{|c|}{ Course Classification } & \multicolumn{2}{|l|}{ Course Name } & Credits & Hours \\
\hline \multirow{7}{*}{$\begin{array}{l}\text { General } \\
\text { Educational } \\
\text { Courses }\end{array}$} & \multirow{2}{*}{ Required } & \multicolumn{2}{|c|}{ College English course (1-2) } & 6 & 96 \\
\hline & & \multicolumn{2}{|c|}{ College English course(3-4) } & 6 & 96 \\
\hline & \multirow{5}{*}{ Selective } & \multicolumn{2}{|c|}{$\begin{array}{l}\text { Humanities and Social Sciences Courses (Inc. Online } \\
\text { Courses) }\end{array}$} & 2 & 32 \\
\hline & & \multicolumn{2}{|c|}{ Natural Science Courses (Inc. Online Courses) } & - & - \\
\hline & & \multirow{3}{*}{$\begin{array}{l}\text { Innovation } \\
\text { Entrepreneurship } \\
\text { Courses }\end{array}$} & $\begin{array}{l}\text { Professional Introduction } \\
\text { Courses }\end{array}$ & - & - \\
\hline & & & Freshman Seminar & 1 & 16 \\
\hline & & & $\begin{array}{l}\text { Entrepreneurial Courses (Inc. } \\
\text { Online Courses) }\end{array}$ & - & - \\
\hline \multicolumn{2}{|c|}{ Specialized Core Courses } & \multicolumn{2}{|c|}{ Specialty English for a certain discipline } & 2 & 32 \\
\hline
\end{tabular}

Note: In selective courses of general education, there are 10 courses related to EFL for choice, including three categories: language skills, English cultures as well as academic English.

\subsection{Graded Teaching Model}

Both required EFL courses at CUGB are taught by network-assisted language teaching (NALT) model that is the integration between traditional classroom instruction and network teaching ( $\mathrm{He}, 2013$; He \& Liu, 2014) with the ratio of hours 2:1. Since September 2015, the graded teaching model has been used in EFL teaching. According to the scores of freshmen's English placement test, the first around 300 freshmen (10 classes totally) were placed in Grade A in 2015, while the left in Grade B. Since 2016, the number of classes of Grade A has been increased to 16 with about 500 freshmen.

On the basis of the MOE document College English Teaching Guidelines, students of Grade A should reach level 4 and pass CET- 4 in the first semester, and reach level 6 and pass CET- 6 in the second semester. By 
contrast, requirement on students of Grade B is lower, that is they need to reach level 4 and pass CET-4 at the end of second semester.

\subsection{Feedback Based on Students' Needs}

According to the multi-dimensional needs analysis of current EFL curriculum system under graded teaching model with the questionnaire and interview to the case of CUGB, findings are as follows:

(1) The passing rates on CET- 4 \& 6 from China's science and technology institutes are only half and even lower and imbalance exists in the development of five English skills, especially listening and speaking.

(2) The current EFL selective courses cannot meet students' needs both from course contents and teaching objectives and effects.

(3) Students are in urgent needs of raising English proficiency related to their majors to meet the future occupational needs. Meanwhile, they think the teaching effect on the required EFL courses is not good under the current teaching model.

According to above surveys of EFL curriculum system, graded teaching model as well as feedback based on students' needs, a conclusion is that the current EFL curriculum system of science and technology institutes under graded teaching model cannot meet the needs of undergraduates' English learning and future career due to the vague and non-specific course classification and insufficient ESP courses and hours, though their curriculum system has been changed into ESP courses. Thus, in this paper, a classification scheme of English teaching is rebuilt at first. And then a new EFL curriculum system under graded teaching model is designed based on learning-centered approach to curriculum design.

\section{A Rebuilding of Classification Scheme of English Teaching}

The classification scheme of foreign language teaching is of a wide variety with different criteria. Hutchinson and Waters (1987a) classified it into GE and ESP which includes EAP and English for Occupational Purposes (EOP). And then based on Hutchinson and Waters' classification, Jordan (1997) subdivided EAP into English for specific academic purposes (ESAP) and English for general academic purposes (EGAP). Yet Cai and Liao (2010) thought that ECH (English courses of the Humanities) should be included into ESP. They defined ECH as the humanities' courses of foreign language, such as British and American Culture, British and American literature, as well as inter-cultural communication etc., which can promote the effective communication. Here, a new classification scheme of English teaching is rebuilt as shown in Figure 1.

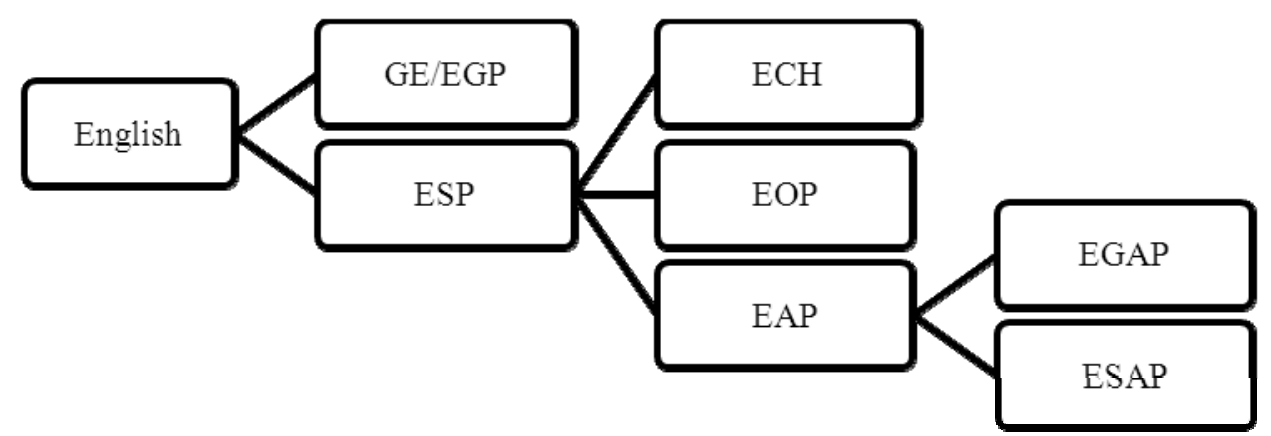

Figure 1. A rebuilding of classification scheme of English teaching

GE/EGP courses are helpful for students' English skills, that is to help them master "the common core" of English (Kong \& Xu, 2011). In fact, it is more usefully considered as providing a broad foundation with general purposes (Far, 2008). The first-year required EFL courses at CUGB just belong to EGP in which the role of students is "information receiver" (Zou, 2013).

ESP is "an approach to language teaching in which all decisions as to content and method are based on the learner's reason for learning" (Hutchinson \& Waters, 1987b; Anthony, 1997), i.e. based on learning-centered approach, and its goal is to provide language instruction that addresses students' own specific language learning purposes and professional needs (Dudley-Evans \& St. Johns, 1998; Belcher, 2009). Therefore, the ESP course design is based on the learners' needs and activation of learning motivation (Zou, 2013).

Furthermore, ESP is classified into three courses in this paper, i.e. EAP, EOP and ECH. EAP refers to "the 
language research and instruction that focuses on the specific communicative needs and practices of particular groups in academic contexts" (Hyland \& Hamp-Lyons, 2002). Due to both common core and subject-specific features (Coffey, 1984), EAP is subdivided into EGAP and ESAP. EGAP is concerned with general academic language and focuses on study skills and focus on study skills, while ESAP examines the language features of particular academic disciplines or subjects, e.g. social sciences, or economics (Jordan, 1989).

EOP refers to "English that is not for academic purposes; it includes professional purposes in administration, medicine, law and business, and vocational purposes for non-professionals in work or pre-work situations" (Dudley-Evans \& St John, 1998). Its courses, such as medical English, are always taught by content teachers.

$\mathrm{ECH}$, in this paper, is added into ESP as an important part to help them understand the national conditions, literature and culture of the English-speaking countries (Jian, 2013) to further promote their inter-cultural communicative competence, since their arts bases as students of science and engineering are weak.

In a word, ESP is a learning-centered approach based on learners' needs analysis while EGP is a knowledge-oriented or skill-oriented one, so ESP is primarily concerned with the learning process rather than only language itself. However, the relationship between EGP and ESP is not foundation and application, but complementation that both of them comprise EFL curriculum system.

\section{EFL Curriculum System Design of China's Science and Technology Institutes under Graded Teaching Model}

A learning-centred approach - an approach with the avowed aim of maximising the potential of the learning situation - to course design (Figure 2) takes account of the learner at every stage of the design process (Hutchinson \& Waters, 1987a).

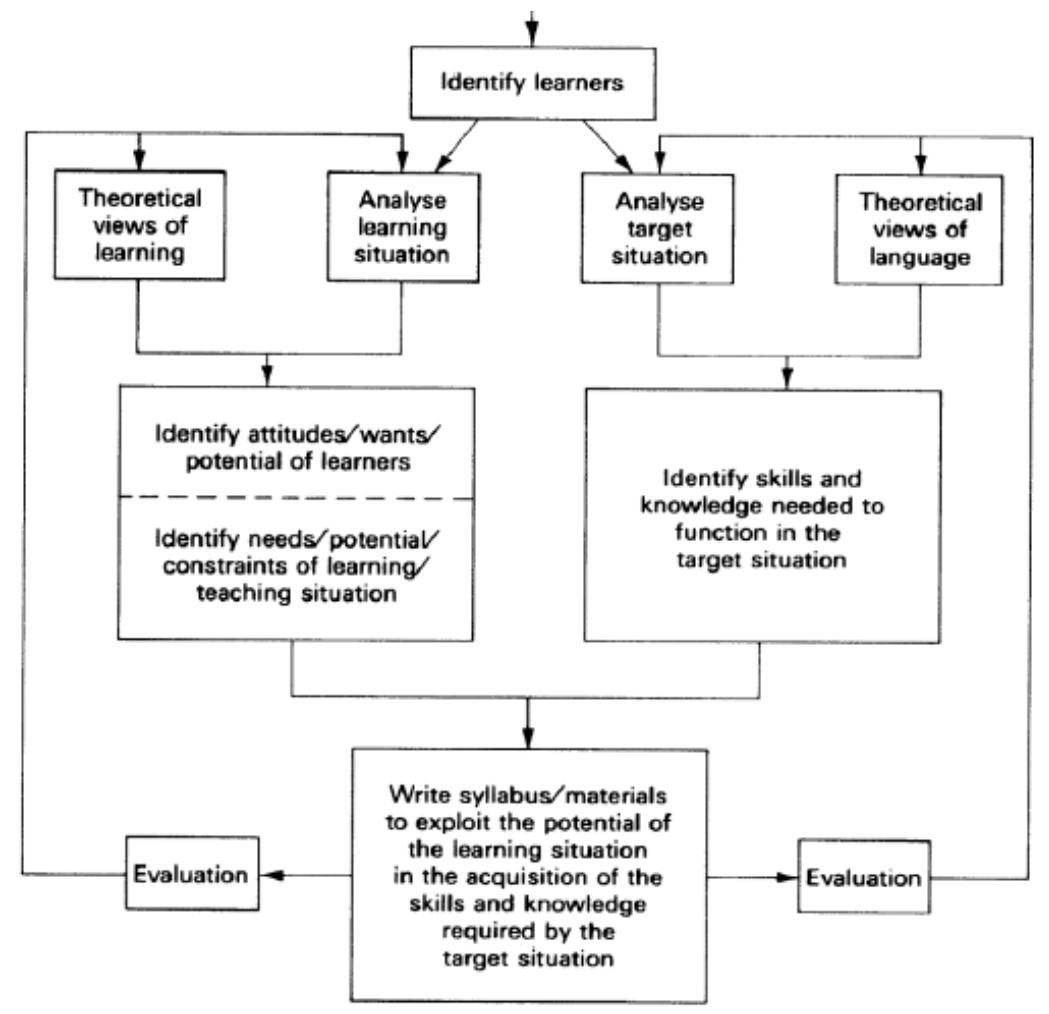

Figure 2. A learning-centred approach to course design (Hutchinson \& Waters, 1987a)

On the basis of learning-centred approach and the survey and analysis on the current EFL curriculum and students' needs, an EFL curriculum system of China's science and technology institutes under graded teaching model is designed. Table 2 and Table 3 are the respective new EFL curriculum system of grade A and grade B. 
Table 2. EFL curriculum system of grade A

\begin{tabular}{|c|c|c|c|c|c|c|}
\hline Semester & Objectives & $\begin{array}{l}\text { Course } \\
\text { category }\end{array}$ & $\begin{array}{l}\text { Teaching } \\
\text { model }\end{array}$ & Hours & Credits & $\begin{array}{l}\text { Evalu- } \\
\text { ation }\end{array}$ \\
\hline 1 & To reach level 6 of EFL & $\begin{array}{l}\text { EGP } \\
\text { (required) }\end{array}$ & NALT & 96 & 6 & Exam \\
\hline \multirow[t]{2}{*}{2} & $\begin{array}{l}\text { To understand bilingual } \\
\text { specialized courses, and } \\
\text { make effective academic } \\
\text { communication with oral } \\
\text { and written English }\end{array}$ & $\begin{array}{l}\text { EGAP } \\
\text { (selective) }\end{array}$ & classroom & 64 & 4 & Paper \\
\hline & $\begin{array}{l}\text { To understand } \\
\text { English-speaking } \\
\text { countries' cultures }\end{array}$ & $\begin{array}{l}\mathrm{ECH} \\
\text { (selective) }\end{array}$ & classroom & 32 & 2 & Paper \\
\hline \multirow[t]{2}{*}{3} & $\begin{array}{l}\text { To understand bilingual } \\
\text { specialized courses, and } \\
\text { make effective academic } \\
\text { communication with oral } \\
\text { and written English }\end{array}$ & $\begin{array}{l}\text { EGAP } \\
\text { (selective) }\end{array}$ & classroom & 64 & 4 & Paper \\
\hline & $\begin{array}{l}\text { To understand } \\
\text { English-speaking } \\
\text { countries' cultures }\end{array}$ & $\begin{array}{l}\mathrm{ECH} \\
\text { (selective) }\end{array}$ & classroom & 32 & 2 & Paper \\
\hline \multirow[t]{2}{*}{4} & $\begin{array}{l}\text { To understand bilingual } \\
\text { specialized courses, and } \\
\text { make effective academic } \\
\text { communication with oral } \\
\text { and written English }\end{array}$ & $\begin{array}{l}\text { EGAP } \\
\text { (selective) }\end{array}$ & classroom & 64 & 4 & Paper \\
\hline & $\begin{array}{l}\text { To understand } \\
\text { English-speaking } \\
\text { countries' cultures }\end{array}$ & $\begin{array}{l}\mathrm{ECH} \\
\text { (selective) }\end{array}$ & classroom & 32 & 2 & Paper \\
\hline \multirow{2}{*}{5} & $\begin{array}{l}\text { To develop the specialized } \\
\text { courses study and } \\
\text { communication in English }\end{array}$ & $\begin{array}{l}\text { ESAP } \\
\text { (selective) }\end{array}$ & classroom & 32 & 2 & Paper \\
\hline & $\begin{array}{l}\text { To understand } \\
\text { English-speaking } \\
\text { countries' cultures }\end{array}$ & $\begin{array}{l}\mathrm{ECH} \\
\text { (selective) }\end{array}$ & classroom & 32 & 2 & Paper \\
\hline \multirow{2}{*}{6} & $\begin{array}{l}\text { To develop the specialized } \\
\text { courses study and } \\
\text { communication in English }\end{array}$ & $\begin{array}{l}\text { ESAP } \\
\text { (selective) }\end{array}$ & classroom & 32 & 2 & Paper \\
\hline & $\begin{array}{l}\text { To understand } \\
\text { English-speaking } \\
\text { countries' cultures }\end{array}$ & $\begin{array}{l}\text { ECH } \\
\text { (selective) }\end{array}$ & classroom & 32 & 2 & Paper \\
\hline \multirow[t]{2}{*}{7} & $\begin{array}{l}\text { To develop English } \\
\text { communicative } \\
\text { competence in specific } \\
\text { occupational contexts }\end{array}$ & $\begin{array}{l}\text { EOP } \\
\text { (selective) }\end{array}$ & $\begin{array}{l}\text { classroom } \\
\text { online }\end{array}$ & / 32 & 2 & Paper \\
\hline & $\begin{array}{l}\text { To understand } \\
\text { English-speaking } \\
\text { countries' cultures }\end{array}$ & $\begin{array}{l}\text { ECH } \\
\text { (selective) }\end{array}$ & classroom & 32 & 2 & Paper \\
\hline 8 & $\begin{array}{l}\text { To develop English } \\
\text { communicative }\end{array}$ & $\begin{array}{l}\text { EOP } \\
\text { (selective) }\end{array}$ & $\begin{array}{l}\text { classroom } \\
\text { online }\end{array}$ & / 32 & 2 & Paper \\
\hline
\end{tabular}


competence in specific

occupational contexts

Note: About the selective courses of ESP, there are additional statements as follows.

1). All the ESP courses is taught by ESP teachers of department of foreign languages except ESAP.

2). Each EGAP course takes 64 hours with 4 credits; students of grade A should select one course at least each semester from the $2^{\text {nd }}$ to $4^{\text {th }}$ semester.

3). Each ECH/ESAP/EOP course takes 32 hours with 2 credits; its minimum required credits are 4.

4). ESP teachers of department of foreign languages and content teachers of other schools cooperate to take ESAP courses. The subject research method is designed as the teaching method of ESAP courses, that is content teachers give some discipline-specific subjects and then each group of the students choose one to conduct the research, referring to literatures, making group discussion on the class, writing report, as well as making a presentation about the study results. In the whole process, ESP teachers should focus on their language skills, while content teachers for professional skills.

5). Minimum required credits of EFL curriculum (EGP \& ESP) is 30.

Table 3. EFL curriculum system of grade B

\begin{tabular}{|c|c|c|c|c|c|c|}
\hline Semester & Objectives & $\begin{array}{l}\text { Course } \\
\text { category }\end{array}$ & $\begin{array}{l}\text { Teaching } \\
\text { model }\end{array}$ & Hours & Credits & $\begin{array}{l}\text { Evalu- } \\
\text { ation }\end{array}$ \\
\hline 1 & To reach level 3 of EFL & $\begin{array}{l}\text { EGP } \\
\text { (required) }\end{array}$ & NALT & 96 & 6 & Exam \\
\hline \multirow{3}{*}{2} & \multirow{2}{*}{ To reach level 4 of EFL } & $\begin{array}{l}\text { EGP } \\
\text { (required) }\end{array}$ & NALT & 96 & 6 & Exam \\
\hline & & $\begin{array}{l}\text { EGP } \\
\text { (required) }\end{array}$ & classroom & 16 & 1 & Exam \\
\hline & $\begin{array}{l}\text { To understand } \\
\text { English-speaking } \\
\text { countries' cultures }\end{array}$ & $\begin{array}{l}\mathrm{ECH} \\
\text { (selective) }\end{array}$ & classroom & 32 & 2 & Paper \\
\hline \multirow{3}{*}{3} & \multirow[t]{2}{*}{ To reach level 6 of EFL } & $\begin{array}{l}\text { EGP } \\
\text { (required) }\end{array}$ & NALT & 96 & 6 & Exam \\
\hline & & $\begin{array}{l}\text { EGP } \\
\text { (required) }\end{array}$ & classroom & 16 & 1 & Exam \\
\hline & $\begin{array}{l}\text { To understand } \\
\text { English-speaking } \\
\text { countries' cultures }\end{array}$ & $\begin{array}{l}\mathrm{ECH} \\
\text { (selective) }\end{array}$ & classroom & 32 & 2 & Paper \\
\hline \multirow[t]{2}{*}{4} & $\begin{array}{l}\text { To understand bilingual } \\
\text { specialized courses, and } \\
\text { make effective academic } \\
\text { communication with oral } \\
\text { and written English }\end{array}$ & $\begin{array}{l}\text { EGAP } \\
\text { (selective) }\end{array}$ & classroom & 64 & 4 & Paper \\
\hline & $\begin{array}{l}\text { To understand } \\
\text { English-speaking } \\
\text { countries' cultures }\end{array}$ & $\begin{array}{l}\mathrm{ECH} \\
\text { (selective) }\end{array}$ & classroom & 32 & 2 & Paper \\
\hline 5 & $\begin{array}{l}\text { To understand bilingual } \\
\text { specialized courses, and } \\
\text { make effective academic } \\
\text { communication with oral } \\
\text { and written English }\end{array}$ & $\begin{array}{l}\text { EGAP } \\
\text { (selective) }\end{array}$ & classroom & 64 & 4 & Paper \\
\hline
\end{tabular}




\begin{tabular}{|c|c|c|c|c|c|c|}
\hline & $\begin{array}{l}\text { To understand } \\
\text { English-speaking } \\
\text { countries' cultures }\end{array}$ & $\begin{array}{l}\mathrm{ECH} \\
\text { (selective) }\end{array}$ & classroom & 32 & 2 & Paper \\
\hline \multirow[t]{2}{*}{6} & $\begin{array}{l}\text { To understand bilingual } \\
\text { specialized courses, and } \\
\text { make effective academic } \\
\text { communication with oral } \\
\text { and written English }\end{array}$ & $\begin{array}{l}\text { EGAP } \\
\text { (selective) }\end{array}$ & classroom & 64 & 4 & Paper \\
\hline & $\begin{array}{l}\text { To understand } \\
\text { English-speaking } \\
\text { countries' cultures }\end{array}$ & $\begin{array}{l}\text { ECH } \\
\text { (selective) }\end{array}$ & classroom & 32 & 2 & Paper \\
\hline \multirow{3}{*}{7} & $\begin{array}{l}\text { To develop the } \\
\text { specialized courses study } \\
\text { and communication in } \\
\text { English }\end{array}$ & $\begin{array}{l}\text { ESAP } \\
\text { (selective) }\end{array}$ & classroom & 32 & 2 & Paper \\
\hline & $\begin{array}{l}\text { To develop English } \\
\text { communicative } \\
\text { competence in specific } \\
\text { occupational contexts }\end{array}$ & $\begin{array}{l}\text { EOP } \\
\text { (selective) }\end{array}$ & $\begin{array}{l}\text { classroom } \\
\text { online }\end{array}$ & / 32 & 2 & Paper \\
\hline & $\begin{array}{l}\text { To understand } \\
\text { English-speaking } \\
\text { countries' cultures }\end{array}$ & $\begin{array}{l}\mathrm{ECH} \\
\text { (selective) }\end{array}$ & classroom & 32 & 2 & Paper \\
\hline \multirow{2}{*}{8} & $\begin{array}{l}\text { To develop the } \\
\text { specialized courses study } \\
\text { and communication in } \\
\text { English }\end{array}$ & $\begin{array}{l}\text { ESAP } \\
\text { (selective) }\end{array}$ & classroom & 32 & 2 & Paper \\
\hline & $\begin{array}{l}\text { To develop English } \\
\text { communicative } \\
\text { competence in specific } \\
\text { occupational contexts }\end{array}$ & $\begin{array}{l}\text { EOP } \\
\text { (selective) }\end{array}$ & $\begin{array}{l}\text { classroom } \\
\text { online }\end{array}$ & / 32 & 2 & Paper \\
\hline
\end{tabular}

Note: About the selective courses of ESP, there are additional statements as follows.

1). All the ESP courses is taught by ESP teachers of department of foreign languages except ESAP.

2). Each EGAP course takes 64 hours with 4 credits; students of grade B should select one course at least each semester from the $4^{\text {th }}$ to $6^{\text {th }}$ semester.

3). Each ECH course takes 32 hours with 2 credits; its minimum required credits are 4.

4). Each ESAP/EOP course takes 32 hours with 2 credits; its minimum required credits are 2.

5). ESP teachers of department of foreign languages and content teachers of other schools cooperate to take ESAP courses. The subject research method is designed as the teaching method of ESAP courses, that is content teachers give some discipline-specific subjects and then each group of the students choose one to conduct the research, referring to literatures, making group discussion on the class, writing report, as well as making a presentation about the study results. In the whole process, ESP teachers should focus on their language skills, while content teachers for professional skills.

6). Minimum required credits of EFL curriculum (EGP \& ESP) of grade B is 40 which is 10 more than of grade A due to the weaker English proficiency of grade B's students. These 10 credits are placed in the EGP courses to develop these students' English skills.

Giving the different English proficiency of freshmen, EFL curriculum system is designed into two sub-systems under graded teaching model, one for grade A's students and the other for grade B's. On the other hand, this system is customized for China's science and technology institutes like CUGB, and therefore, more EGP and ECH courses are designed in this system to promote students' English skills and literature cultivation. That is to 
say, this system is designed based on learners' needs. Furthermore, on basis of learning-centred approach, EFL courses are covered in all the 8 semesters and ESP courses take up 7 semesters, which indicates that EFL courses is ESP courses in fact and these courses learning is a long process and the learning process is what ESP teachers focus on.

\section{Conclusion}

This paper started off with the survey and finding on the current situations of China's EFL curriculum. The study has attempted to contribute to this survey and finding by rebuilding the classification scheme of English teaching and then designing a new EFL curriculum system of China's science and technology institutes under graded teaching model further, based on learning-centred approach and learners' needs theory. In this system, EFL teaching has become the ESP teaching in fact, and the teaching objectives are no longer the English skills but the future occupational development that meets students' needs indeed. Therefore, the role of English as a language tool is embodied, which is the basis of setting EFL teaching objectives. Equally worthy of mention is the collaboration between ESP teachers and content teachers in ESAP courses using the subject research method, which can be studied in the future work.

\section{Acknowledgements}

The authors would like to sincerely express thanks for the support from the Fundamental Research Funds for the Central Universities under Grant 53200859061.

\section{References}

Anthony, L. (1997). Defining English for specific purposes and the role of the ESP practitioner. Retrieved November, 18, 2008.

Belcher, D. (2009). What ESP is and can be: An introduction. In D. Belcher (Ed.), English for Specific Purposes in theory and in practice (pp. 1-21). Ann Arbor: University of Michigan Press. https://doi.org/10.3998/mpub.770237

Cai, J., \& Liao, L. (2010). EAP vs. ESP-The orientation of college English. Foreign Language Education, 31(6), 47-50, 73. https://doi.org/10.16362/j.cnki.cn61-1023/h.2010.06.022

Cai, J. (2012). A way out for EFL at tertiary level education in mainland China. Shanghai: Shanghai Jiao Tong University Press.

Coffey, B. (1984). ESP-English for Specific Purposes. Language Teaching, 17(1), 2-16. https://doi.org/10.1017/S0261444800010405

Conway, J. (2010). Civilian language education in America: how the air force and academia can thrive together. Air \& Space Power Journal,4 (4): 20-33.

Dudley-Evans, T., \& St John, M. J. (1998). Developments in English for specific purposes: A multi-disciplinary approach. Cambridge: Cambridge University Press.

Far, M. M. (2008). On the relationship between ESP \& EGP: A general perspective. English for Specific Purposes World, 7(1), 1-11.

Feng, Y. (2010). Disciplinary transfer: Inevitable choice for professional development of common core foreign language teachers. University Education Science, (3), 67-72.

He, C., \& Liu, W. (2014). Study of the effect of NALT model on fostering undergraduate autonomy. Saarbrücken: LAP LAMBERT Academic Publishing.

He, C. (2013). Effect of network-assisted language teaching model on undergraduate English skills. English Language Teaching, 6 6), 29. https://doi.org/10.5539/elt.v6n6p29

Hutchinson, T., \& Waters, A. (1987a). English for specific purpose. Cambridge: Cambridge University Press. https://doi.org/10.1017/CBO9780511733031

Hutchinson, T., \& Waters, A. (1987b). English for specific purposes-A learning-centered approach. Cambridge: Cambridge University Press. https://doi.org/10.1017/CBO9780511733031

Hyland, K., \& Hamp-Lyons, L. (2002). EAP: Issues and directions. Journal of English for academic purposes, 1(1), 1-12. https://doi.org/10.1016/S1475-1585(02)00002-4

Jian, S. (2013). Some tentative proposals to the current reform of Chinese college English teaching on the basis of needs analysis. English Language Teaching, 6(7), 79. https://doi.org/10.5539/elt.v6n7p79 
Jordan, R. R. (1989). English for academic purposes (EAP). Language Teaching, 22(3), 150-164. https://doi.org/10.1017/S026144480001483X

Jordan, R. R. (1997). English for academic purposes: a guide and resource book for teachers. Cambridge: Cambridge University Press. https://doi.org/10.1017/CBO9780511733062

Kong, Y., Xu, N. (2011). Study of the integration of EGP and ESP at tertiary level education. Journal of Southwest Agricultural University (Social Sciences Edition), 9(1), 165-167.

Leaver, B. L., \& Stryker, S. B. (1989). Content-based instruction for foreign language classrooms. Foreign Language Annals, 22(3), 269-275. https://doi.org/10.1111/j.1944-9720.1989.tb02746.x

Ministry of Education (MOE). (2010). National Plan for Medium and Long-term Education Reform and Development (2010-2020). $\quad$ Retrieved July 9, 2017, $\quad$ from http://www.gov.cn/jrzg/2010-07/29/content_1667143.htm

Wen, Q. (2012). The challenges and strategies faced with college English from the perspective of curriculum theory. Foreign Language Teaching and Research, 44 (2), 283-292.

Wen, Q. (2014). On the debate of EGP and ESP in current college English teaching: problem and countermeasure. Foreign Languages and Their Teaching, (1), 1-8. https://doi.org/10.13458/j.cnki.flatt.004408

Zou, W. (2013). Towards a new paradigm for English teaching and learning in higher education. Foreign Languages and Their Teaching, (5), 10-13. https://doi.org/10.13458/j.cnki.flatt.003956

\section{Copyrights}

Copyright for this article is retained by the author(s), with first publication rights granted to the journal.

This is an open-access article distributed under the terms and conditions of the Creative Commons Attribution license (http://creativecommons.org/licenses/by/4.0/). 